\title{
The Basic Ideas of the Concept of Professionally-Motivating Industrial Art Education
}

\author{
Boris Vladimirovich Ilkevich ${ }^{1}$, Konstantin Borisovich Ilkevich ${ }^{1} \&$ Vadim Vadimovich Nikonov \\ ${ }^{1}$ Gzhel State Art and Industry Institute, Russia \\ Correspondence: Boris Vladimirovich Ilkevich, Gzhel State Art and Industry Institute, Ramensky region, \\ Elektroizolyator, 140155, Russia. E-mail: ilk_bv@mail.ru
}

Received: September 23, 2014

Accepted: November 17, 2014 Online Published: December 2, 2014

doi:10.5539/ass.v11n1p347

URL: http://dx.doi.org/10.5539/ass.v11n1p347

\begin{abstract}
The purpose of the article is to develop the concept of professionally- motivating Industrial Art education, methodological guideline for which appear the ideas of implementing a humanistic paradigm of Industrial Art Education in Russia. The paper presents the main ideas of the concept of professionally motivating Industrial Art Education that allows to specify the basic requirements for the educational goals and process, driving forces, teaching methods, syllabus, the requirements for teachers and students, as well as the eventual result which supposes a high level of professional motivation, students' commitment to professional skills, self-education, ability to apply the acquired knowledge in the art craft, to improve individually. The article issues are theoretically and practically important for the administration and teaching staff of vocational education institutions within organization of professionally-motivating Industrial Art Education.
\end{abstract}

Keywords: concept, professionally-motivating education, Industrial Art Education, regional education, folk arts and crafts, Gzhel region

\section{Introduction}

The System of Industrial Art Education (IAE) comprises a complex of public and private educational institutions that provide organizational and substantial unity and successive interrelation of all constituents that solve the problems of Industrial Art professional education with regard to the public, social and personal needs. At present, more than 30 universities and 40 secondary educational institutions train students for artistic careers (Ilkevich \& Ilkevich, 2010).

The problem of professionally-motivating Industrial Art Education in the region is to be solved primarily in terms of general didactics and particularities of a certain region (Ilkevich, 2011; Beyrami \& Talebi, 2012; Tabatabaei \& Arjmand, 2013). The example of regional education is the professional education system of Gzhel that meets the need of the production associations and enterprises in highly-professional specialists in various fields, preferably young people from the region. This is achieved through the integration of educational institutions, agencies, organizations and mass media. The organizational unity of the educational sphere of the Gzhel State Art and Crafts Institute, which has been educating specialists for more than 100 years in the field of arts and crafts and handicrafts, appears simultaneously a condition, a form, the implementation result of the genuine integrity of the education content as a significant social experience, adapted to be handed from generation to generation (Ilkevich \& Sukhodolova, 2011; Lisitzina, 2010).

\section{Literature Review}

The major problems of educational theory and practice in this field appear unsatisfactory development of conceptual ideas and issues of professionally motivating Industrial Art Education.

Exploring motivation is a significant problem in modern pedagogy and psychology. In the works by V. G. Aseyev (1976), O. V. Vishtak (2003), E. P. Ilyin (2004) there are the discussions of the place and the role of professional motives in the structure of the individual motivational sphere. The motivational sphere of a person and peculiarities of its formation are revealed in the works by A. Z. Aplashova, B. A. Amirova, S. K. Abildina, M. M. Tusupova, U. I. Autalipova (2014), V. A. Popov, O. Y. Kondratyeva (1999), D. Dubovitskaya (2003) and others. To the motives of action and the mechanisms of their formation are devoted the papers by A. G. Bugrimenko (2006), Verbitsky A. A., N. A. Bakshaeva (1998). The studies by O. S. Gribenyuk, T. B. Gribenyuk 
(1998), G. I. Shchukina (1986) and others indicate that the formation of professional motivation through educational activities is the most effective.

The analysis of the works of the abovementioned authors and many other publications in the topic showed that the issues related to the research of the professionally-motivating Industrial Art Education problem remain an understudied area of scientific knowledge and practical activities that has brought to development of the problem conceptual ideas.

\section{Methodological Framework}

In a situation of steady development the formation of the legal framework of the Russian Industrial Art Education should be as follows: National Doctrine of Education - the Federal Program of the Education Development - the Federal Law "About Education" - a series of elaborating legislative acts relating to the actual Industrial Art Education. However, during the economic and social crisis, a crisis of Russian culture, this logic has been distorted and the legislative course has been changed to the opposite. In 1992 the first edition of the Russian Federation Law "About Education" was adopted and in 1994 the government approved the Federal program of the Education development which has not been performed, and in early 1998 was withdrawn from the State Duma (Russian Federation Law "On Education", 1992). The new edition of the Education development program for 2000 - 2005 was endorsed by the Russian Government in June, 1999 and approved by the State Duma in April, 2000 (The decision of the Government of the Russian Federation "On approval of the project by the Federal Programme for the Development of Education", 1994). Only after that, in October, 2000 the government approved the National Doctrine of Education in the Russian Federation (Federal Law of April 10, 2000; National Doctrine of Education in the Russian Federation, 2000). The existing legal framework could not serve as the basis for conceptual approaches of the Ministry of Education in reforming Industrial Art Education in Russia.

Hereafter the Federal target programs of the Education development were subsequently approved: for 2006 2010 (in December, 2005), 2011 - 2015 (in February, 2011) (Resolution of the Government of the Russian Federation, 2005; Resolution of the Government of the Russian Federation, 2011). The Decree of the Russian Federation Government dated 15.05.2013 approved the program "Education Development" for 2013 - 2020 (Order of the Government of the Russian Federation, 2013). In December 2012, the Federal Law "About Education in the Russian Federation" was enabled, it came into operation on September, 1, 2013 (Federal Law "On Education in the Russian Federation", 2012).

The issue of professional education, to which the Industrial Art Education refers in the existing and preceding Federal laws and programs is insufficient although important. The educational process should satisfy the need of the individual in intellectual, cultural and moral development. In this case, the abovementioned documents dispute the professional education motivation, but particularly it discusses only general motivation to obtain new knowledge, to aspire lifelong learning. In particular, one of the objectives of the Federal target program for the education development in 2006 - 2010 stated: "the harmonious development of the individual and his creative abilities on the basis of motivation for education and self-education throughout life". The Federal Law "About Education in the Russian Federation" states that "education is a purposeful process of organizing students' activities while acquiring knowledge, skills and competencies, experience and then practical application of knowledge in everyday life; as well as developing students' thirst for education throughout their lives".

Thus, a characteristic feature of the existing legal documents is underestimating the social sphere of human life; the objectives and tasks of professional education statement do not contain socially valuable sense of professional competence. The documents also do not take into account the fact that a specialist may be highly educated, highly skilled, inspired for lifelong learning, able to work, but at the same time do not love the profession acquired in high school and do not work by his profession. Meanwhile, many teachers state there is the lack of correlation between personal and professional components of the students' and graduates' consciousness, including Arts and Industry students receiving education in specialties of "Industrial Art and Folk arts."

It is worth mentioning the concept of "professionalism" in Russia and other countries is explained differently. We understand professionalism as the highest degree of excellence in a particular activity, while Americans, for example, mean a mission that is manifested through a set of special knowledge, social responsibility and corporatism. The spiritual basis of Industrial Arts corporatism is axiological unity of the folk crafts artists, their self- determination as a community of professionals - adherents of the folk art.

The national, social and professional approaches to the definition of the objectives of Industrial Art Education seem to be insufficient in the documents relating to the folk arts and crafts, their condition and development. In 
particular, the Federal Law of January 6, 1999 № 7-FZ "About folk art crafts" does not mention a word about Industrial Art Education, staff training for the folk arts field (Federal Law "On the popular handicrafts", 1999).

The Law of the Moscow region of 17.11.2000 № 77 / 2000-03 "About the folk art crafts in the Moscow region" (corrected and amended), Article 12 states: "1. The organizations of folk arts crafts provide the conditions for educational training of the stuff for artistic professions; teaching them basics skills; continuous improvement of their qualification, skill level and proficiency; stimulation of creative activity. 2. Training the stuff for folk arts and crafts is organized in the educational institutions of primary, secondary and higher education, as well as it can be performed in educational institutions that implement various programs of additional education. " These generalities do not reflect the goals and content of Industrial Art Education, and convincingly show how the state and society are far from the objective-setting issues in the training of artistic stuff for Arts and Crafts and Folk art (Law of the Moscow region "On the popular handicrafts in the Moscow region", 2000).

The Conception of the state support of the folk arts and crafts organizations for the period up to 2015, approved by the Order of the Ministry of Industry and Trade on September, 24, 2009 № 854, stated the only problem regarding education: "monitoring (inventory) of the educational institutions that train staff for folk arts and crafts and their current condition", which was to be performed on the first (organizational and preparatory) phase of taking measures (2009 - 2010) (The concept of state support organizations folk arts and crafts for the period until 2015, 2009). At the second (defining) and the third (basic) stages the question of education and educational institutions was not mentioned. It remains unclear how without the development of Industrial Art Education the projected results of the government support measures referred to in the concept will be achieved, including conservation of traditions, culture and identity of national art crafts of Russia; providing steady state of the folk arts and crafts institutions; stuff retention and extending vacancies, attracting talented young people; ensuring economic stability of the national art crafts organizations, development of the regions. None of these problems can be solved without highly professional and what is more important professionally-motivated artists-craftsmen, folk art specialists.

The requirements for the technical characteristics in the research work " the Development Strategy of the folk artistic craft for the period up to 2020 and an action plan for its implementation" (code "C-NHP") states that one of the strategy goals is the integration of the folk artistic craft complex product in tourism and education, shaping the image of Russia and its investment appeal (Tender 1-5831414, 2013). It is mentioned that to achieve the purpose it is necessary "to include information about folk artistic craft into educational programs, to use folk craft products as visual aids in pre-school and school education." In addition, the series of measures for conservation and development of folk artistic craft include the following paragraph: "training and retention of professional staff for folk artistic craft (including measures to improve the social status (public recognition) of the folk craft artists and craftsmen, their encouragement and stimulation)". In general, the analysis of the performance requirements in the aforementioned research work shows that there are some issues of Industrial Art Education included into the future development strategies of national art crafts, but not amount that is necessary. The most bewildering fact is that the usage of folk art craft products are limited within pre-school and school education. It seems that the folk craft products "has not grown up to" higher education.

The state program of the Russian Federation "Education Development " for 2013 - 2020 sets the objectives and tasks, drafts the ways of their implementation. However, the proposed measures are also of organizational nature realized by "the development of effective financial and economic controlling mechanisms". They stimulate motivation to achieve material welfare, both in school and in future work. The reform of higher education does not affect the deep fundamentals of professional activities, internal motives of the specialists. The tasks of the development program do not fully reflect the values and ideals (government, social and private) of higher education including Industrial Art, so they turn out alien. None of the problems of education sets the task to educate younger generation and none of them meets the National Doctrine of Education in the Russian Federation (approved by the Decree of the Government of the Russian Federation on October, 4, 2000, N 751), where the main goals and objectives of education for the period up to 2025 were determined.

All aforementioned documents relating to the education and folk arts and crafts development include a large number of organizational, material and technical, financial measures. In order to reform the system of vocational education the existing conceptual approaches of the Ministry of Education and Science are directed generally to optimize the network structure and capacity of educational institutions; to create public contracts for stuff training (monitor target figures of students admission). However, there is no emphasis on bringing up young professionals, setting their internal professional motivation and love for profession. Apparently, the authors of the development programs believe that economic measures will provide a sufficient desire to learn and work by 
their profession. They do not take into account that the external professional motivation is inconsistent and depends on many various factors.

\section{Results and Discussions}

\subsection{Foundations of Designing the Concept}

In current socio-political conditions the particular value of Industrial Art Education (IAE) and the purposes formed on its basis become very important. The National Doctrine of Education and existing legislative acts emphasize the priorities of peculiar education value, humanistic nature of education and the right for free personality development. So, nowadays the formation of educational and value orientations submit to the inductive logic, in which personal values and education objectives determine the national and public ones. The national and social values of the Industrial Art Education are the product of integration of individual values. In this regard, there is a danger of Industrial Art Education destruction when national values are projected in individualistic, materialistic focuses peculiar to market capitalism over the immature national and social policy interests and goals. While assessing the value of Industrial Art Education the deductive logic should remain prevalent: the artist-master conscious of the national (social) interests, forms on its basis the axiological and target components of his education. Chiefly it concerns the students who are trained to work in folk crafts. The knowledge and skills necessary to work in the field of traditional folk crafts are primarily of the national value and purpose, and the artist should understand their importance. Of course, speaking of Industrial Art Education it is necessary to remember about the unity of the national, social and personal components of the category "Industrial Art Education as a value," its systemacity and integrity. But we cannot forget about the specific content of Industrial Art Education, the essence of which is determined by the words "folk art, folk creativity." And folk crafts, traditional folk art belong to the national Russian heritage (Ilkevich, 2011).

The next point to discuss is that the young man entering the Industrial Art university can have an inaccurate idea of the Industrial Art values. The applicant does not always understand himself the subject of education- the traditional Applied and Decorative Arts - idealizes it. As a result the applicant sticks to incorrect beliefs about the opportunity to develop into an artist of national art crafts and Industrial Art becomes a high personal value. Regrettably a university education is limited mostly with the subject-activity boundaries, while the inner motives and values of Industrial Art Education remain unclaimed. In the absence of a unified ideological attitude the young man is forced to develop his own philosophy of education, which helps him to understand the assignment of a folk artist, adds a personal sense to the educational process and determines educational objectives. If this does not happen, then losing inner motivation in the process of studying the student is often incapable to continue his education as the external motives are unstable and rapidly disappear with the appropriate circumstances.

According to the Law "About Education in the Russian Federation", the objectives of higher and secondary vocational education regard its content and methods as the means for achieving the harmonious development of the emotional, mental, axiological, volitional and physical aspects of the personality. However, social activity and creativity of the educated person involved in the community activities are not possible without internal professional motivation. The content of the teaching lessons that arises no interest and the methods that do not stimulate learning motivation cannot provide true development of a person, his cognitive and social activity. On the other hand, strong learning motivation determines excellent learning results which become a powerful professionally-motivating factor.

Unfortunately, at present time the content of Industrial Art Education is constructed materialistically. Encyclopedism prevails in general education, general professional and special disciplines content. In such circumstances, the teacher tries to "embrace the boundless" and pays no attention to the development of the students' cognitive and motivational spheres. Such a situation can be caused by the following factors: 1) low pedagogical qualifications of the teaching staff. Most teachers are good artists, experts in a particular field of arts and crafts, but poor educators; 2) insufficient training of the management staff; a formal approach to the assessment of the didactic level of the educational process at universities and colleges; 3) the discipline objectives lack focusing on developing inner professional motivation, development of mental abilities, emotional sphere, and psychological qualities.

These reasons are largely subjective and can be largely eliminated by special arrangements. The concept basis of the goals and objectives formation, and hence the content, choice of teaching methods in the Industrial Art university should be the following: Industrial Art Education is intended not only to enrich human knowledge, but also to impart the desire to use it in the field of traditional arts, improve professional skills. Such an approach 
will ensure a harmonious combination of subject, functional, creative and motivational components of content and teaching methods.

Thus, ideological pluralism at the national level, the low development level of the state and society, their inability (or reluctance) to recognize existing values of Industrial Art Education (national, social and private), understand the reasons of the weakening Russian folk crafts beyond poor supply stipulate non-national, non-social, non-pedagogical and non-professional goals and objectives. These ones do not reflect the axiological essence of Industrial Art Education, its national (social) orientation, do not require students' involvement into traditional arts and crafts and desire to apply their professional knowledge. The content and teaching methods are sufficiently dry and materialistic, do not provide cognitive and motivational development, which is inconsistent with the existing negative dynamics of professional motivation in the educational process and the need to take proactive measures to shape motives until the students graduate. As a result, the system of Industrial Art Education is preparing a lot of highly skilled professionals capable of professional work, but not wishing to work in the "low-estimated" field - the field of traditional arts and crafts, for the enterprises of folk arts and crafts, for the respective educational institutions. The national moneys are thrown away, the graduates from Art universities having received a free education in "Arts and Crafts" and "Applied Art and Crafts," find themselves in various fields of art and culture not associated with folk art.

The duty of the state executives is to understand this and fix the social orientation of professional education by law and Industrial Art among other in the form of educational purposes including formation and development of students interest in the chosen profession, the desire to apply their professional knowledge.

Under current conditions while Russia is building a humanistic, democratic society in a market economy, training in Industrial Art university should be qualitatively different, complying with the demands of Industrial Art Education "consumers" - state, society and individuals. Modern Industrial Art Education is able to and should be professionally motivating.

\subsection{Basic Ideas of the Concept}

1. The education of the students should be primarily political and social, and then personal. When it comes to coordination of national (social) and personal Industrial Art values, the emphasis should be placed on national (social) ideals. Only such a correlation between axiological elements of Industrial Art Education creates the necessary conditions for training and education of folk artist with advanced professional motivation, high moral qualities, ready to work in the traditional folk arts and crafts regions, store and enrich national tradition.

2. High Industrial Art motivation should be considered as a priority objective and the main result of Industrial Art Education, arising from its axiological essence. One of the main directions of improving the students preparation should become intensive work towards inner Industrial Art motivation, which on the one hand will ensure stable recruiting of crafts specialists for the field, and on the other hand approach to the productive humanistic paradigm of Industrial Art Education, to provide subject - subject relationship between a teacher and a student - future artist.

3. The educational motives, interest to the profession of an artist can not only serve a means that determines the effective acquisition of knowledge and skills, personal development of the student. It is necessary to ensure mutual transformation of educational and professional motives of artistic creation, which is essential for understanding peculiar value of Industrial Art Education and a high level of professional motivation of the graduate from Industrial Art University.

The stated provisions of the concept of professionally motivating Industrial Art Education develop the characteristics of emerging humanist pedagogy of cooperation that treats motivational course as follows:

- one of the main goals of education - the development of inner artistic motivation, creative, intellectual and spiritual abilities, interests, shaping students' patriotic worldview;

- driving forces of education - professional and educational Industrial Art motives, creativity joy, feeling professional growth and improvement, incrementing artistic knowledge and self-confidence;

- teaching methods - a joint Industrial Art activity, creative pursuit, heuristic dialogue based on common goals of professional development;

- learning content - the development of learning styles in the the field of arts and crafts, reforms in the sphere of folk art, surrounding reality and itself, which are federally, socially and personally meaningful. The knowledge, skills, methods, ways of action required for a successful Industrial Art activities; 
- organization of the educational process - development of the lessons tasks by joint efforts of participators within professionally- motivating educational activities, solution of Industrial Art problem tasks: the group and individual work should be dominant but there should also come a short-term stage of teacher-centered work to approximate the procedural purpose of forming Industrial Art motivation;

- the requirements for the teacher - being an assistant to master professional skills, demonstrate the high Industrial Art motivation, organize and engage students in an active process of solving cognitive and professional tasks, to ensure transformation of secondary motives of artistic creation into the professional motives of Industrial Art activities;

- the requirements for the student - to actively cooperate with all participants of the educational process, improve motivational and intellectual sphere, seek to develop abilities and needs, to realize the government (social) priority of Industrial Art values and goals, duty of the folk artist, responsibility for the fate of the national culture, traditional arts and crafts;

- one of the main learning results - high Industrial Art motivation, aspiration for mastership, self-education, the ability to transfer the acquired knowledge to new situations of professional activity in the folk arts, understand and improve personally.

\section{Conclusion}

The developed concept of professionally-motivating Industrial Art Education of the students develop the differential characteristics of the emerging humanist pedagogy of cooperation and focus on the following urgent tasks:

- in socio-pedagogical aspect: providing high Industrial Art motivation; commitment to professional skills, self-education, the ability to apply the acquired knowledge in new situations of professional activity in the folk art, to understand and improve personally;

- in terms of organization: the organization of the educational process including development of the lessons tasks by joint efforts of participators within professionally- motivating educational activities, solution of Industrial Art problem tasks, the group and individual work is prevailing but there should also come a short-term stage of teacher-centered work to approximate the procedural purpose of forming Industrial Art motivation;

- in terms of content: acquisition of learning styles in the field of arts and crafts, nationally, socially and personally meaningful reforms in the sphere of folk art, environment and themselves. Knowledge, skills, methods, activities required for a successful Industrial Art activities;

- in terms of methods: the integration of innovative and traditional technologies, forms and methods of the joint Industrial Art activities, creative search, heuristic dialogue based on common goals of professional development.

\section{References}

Federal Law of 29 December 2012, № 273-FZ "On Education in the Russian Federation."

Federal Law of April 10, 2000, № 51-FZ "On the approval of the federal program of education."

Federal Law of January 6, 1999 № 7-FZ "On the popular handicrafts."

Ilkevich, B. V. (2011a). Problems and Prospects of Industrial Arts Education. Pedagogy, 6, 80-88.

Ilkevich, B. V. (2011b). Value characteristics of Industrial Arts Education. Philosophy of Education, 3, 142-147.

Ilkevich, B. V., \& Ilkevich, K. B. (2010). Fundamentals of Industrial Arts Education (p. 124). Gzhel: GGHPI Press.

Ilkevich, B. V., \& Sukhodolova E. P. (2011). Industrial Art Education in Gzhel. Higher education today, 3, 58-61.

Law of the Moscow region on November 17, 2000, № 77 / 2000-03 "On the popular handicrafts in the Moscow region."

Lisitzina, T. B. (2007). Vocational and motivational training of students majoring in "Tourism" in the conditions of the region (Thesis). Kazan: 210.

National Doctrine of Education in the Russian Federation (approved by the Decree of the Government of the Russian Federation of October 4, 2000, № 751).

Order of the Government of the Russian Federation on May 15, 2013, № 792-p "On approval of the state program of the Russian Federation" Development of Education "on 2013-2020 period." 
Ramakrishnan, R., \& Dhanya, P. (2014). Mobile Usage among Youngsters - Prediction of Factors that Might Influence Addiction. Journal of Technology, 6, 231-239.

Resolution of the Government of the Russian Federation of 23 December, 2005, № 803 "On the Federal Target Programme for the Development of Education in 2006-2010."

Resolution of the Government of the Russian Federation of February 7, 2011, № 61 "On the Federal Target Programme for the Development of Education in 2011-2015."

Russian Federation Law "On Education" from July 10, 1992, № 3266-1.

Tender (tender) 1-5831414 from 05.04.2013. Order № 017310000513000113. Unique number of purchases 110/19-RDP-05.04OK. Customer Ministry of Industry and Trade of Russia.

The concept of state support organizations folk arts and crafts for the period until 2015 (approved by the Order of the Ministry of Industry and Trade of Russia September 24, 2009, № 854).

The decision of the Government of the Russian Federation "On approval of the project by the Federal Programme for the Development of Education" (report dated March 31, 1994, 5).

\section{Copyrights}

Copyright for this article is retained by the author(s), with first publication rights granted to the journal.

This is an open-access article distributed under the terms and conditions of the Creative Commons Attribution license (http://creativecommons.org/licenses/by/3.0/). 